\title{
Editorial
}

\section{LAW AND FINANCE AS A DISTINCT FIELD OF RESEARCH}

This issue of the European Business Organization Law Review is devoted to the full range of fundamental problems in the field of law and finance. At the same time, it highlights the major disruptions of financial markets at the example of these issues. Ultimately, this raises the forward-looking question about changes for the paradigm in law and economics possibly resulting therefrom. The articles in this issue originate from papers and proceedings of the kick-off conference for the new doctorate and PhD programme at the Goethe University on 'Law and Economics of Money and Finance in Times of Financial Crisis', which took place at the House of Finance/Goethe University of Frankfurt on 15 and 16 May 2009. As programme directors and organisers of the conference, we are proud and delighted that so many outstanding scholars from Europe and the United States agreed to present a paper and participate in the ensuing, most lively discussions, thus contributing to a very prolific intellectual exchange and a very successful kick-off of our programme to be launched this fall term. This is all the more remarkable as everybody had to make an additional effort because of the interdisciplinarity of our agenda. Since we wanted to highlight the underlying economic structure of each problem and possibly also provide regulatory answers, we grouped speakers from economics and law together in each panel to obtain a complete picture. We would therefore like to take this opportunity to thank everyone again for their support. We would also like to express our gratitude for the financial support from the Förderfonds of the Goethe University and for the most generous grant from the Stiftung Geld und Währung, making the entire doctorate and $\mathrm{PhD}$ programme possible.

Law and finance has been established as a distinct field of research only over the last ten to twenty years and it has come to exist in times of growing capital markets very different from today's situation of financial turmoil. Law and finance was increasingly moving into the focus of interdisciplinary research at the time of the takeover movement during the eighties of the last century in the United States, with the firm constituting the nexus between the economic market for corporate control and legal entities as market participants. It has taken a while, however, for this trend to spill over to Europe. It was not until the takeover fight for Mannesmann in 2000 that takeover law has been on the agenda of European capital market law. Only shortly before that, the link between law and finance had been explicitly established in an often-cited article written by La Porta, Lopez-deSilanes, Shleifer and Vishny (Journal of Political Economy (1998) p. 106). With this, the crucial question of capital market development and its driving forces was put on the agenda and has been at the centre of research in law and finance ever 
since. It is closely tied to the question concerning the relationship between economic institutions and legal rules, thus marking a departure from neoclassical concepts of capital markets. From this point of view, institutions play an important role in financial theory, just as was fundamentally noted earlier in the more comprehensive law and economics movement with the ground-breaking work of Coase, Calabresi, and Posner.

\section{LAW AND FINANCE THROUGHOUT THE FINANCIAL CRISIS}

Over the last decade, this strand of research has been focusing in part on how to promote efficiency by way of optimising institutions, thus directing its attention towards a first-best solution. It stands to reason that, in light of the shattering financial crisis, this approach has come under attack because of its inherent belief in markets' rationality. The obvious question on the agenda now is whether the crisis will give rise to a change in paradigm in financial economics or whether it will simply contribute to a refinement of existing methods and perspectives. The first alternative may be initiated by the growing importance of behavioural economics that has brought to bear psychological insights in economics in general and in finance in particular, thus calling into question market rationality. On the other hand, it has been argued that the institutional approach neglected an essential aspect of market rationality in its analyses insofar as it did not pay close enough attention to the fact that there should be a certain correlation between cost and benefit for the market to work, the so-called 'there is no free lunch' idea. Under this second view, of course, the focus would be on improving and complementing existing theory rather than entirely replacing it with something else.

The papers presented here look at exemplary issues raised throughout the crisis, drawing on and trying to effectuate institutional approaches or referring to a new paradigm to deal with these problems more effectively or to avoid them altogether in the future. The full range of topics covered shows the enormous repercussions of the crisis, grouped around what can be considered the classic issues of law and finance. According to conventional wisdom in law and finance, the market for corporate control is the point of departure for research in this field. It is the driving force for capital market development and an investment-driven financial system, establishing the essential link between the firm and the capital market as its source of finance.

The growing importance of the takeover market mentioned above brought about far-reaching changes for the role of intermediaries in the financial system. Instead of channelling money from households to industry, banks now started to focus on directing money from firms with surplus funds to those with surplus investment projects. It is obvious that such a development raises issues of risk and governance with respect to banks. Central banks have been playing an increasingly important role, not only in their capacity as 'lenders of last resort'. As 
members of the Bank for International Settlement, central banks also contribute, via the Basel II framework, to comprehensive measures of capital supervision and risk management, since the Basel Committee on Banking Supervision is a standing committee of the Bank for International Settlement.

In addition to this control of banks by way of risk regulation, another need for control may arise from the growing importance of the market for corporate control and the resulting change of banks' role in channelling funds. The question may occur whether the specific function of banks with respect to the overview of corporations can still be performed once takeover markets flourish. General corporate governance may have to be strengthened in order to assure sufficient control because corporations with surplus funds are immune to outside influence and oversight and may therefore turn out to be resistant to any meaningful control along the lines of traditional corporate governance mechanisms. In fact, this may account for the widely spread shareholder activism among private equity funds which in part meet the requirements of improved shareholder control.

However, the impact of the takeover market not only touches on risk management in such a fundamental sense. It has also brought about a structural change of the financial system as a whole. In addition, new innovative financial instruments have come into being such as, among others, the highly criticised asset-backed securities. These instruments have two dimensions to be particularly noted in the context of law and finance. First, their marketing comes to mind, touching on questions of retail finance. Second, their significance as financial instruments is obvious not only in corporate banking but also in finance for small and medium-sized enterprises. The latter point has two further dimensions, one referring to the different covenants to be stipulated when striking an innovative financial agreement. The second aspect, then, is searching for the most suitable investment vehicle for a small business to raise money from investors, a question which is becoming ever more important in the aftermath of the case law of the European Court of Justice in Centros, Überseering and Inspire Art. Recent reforms with respect to organisational form for small businesses and the introduction of new unincorporated business entities, such as the Companies Act 2006 or the so-called MoMiG Reform in Germany, show that European legislators have recognised the need to compete for investment in their countries.

\section{OVERVIEW OF THE ARTICLES}

Starting from the common point of reference of both law and finance stated above, the takeover market has experienced considerable changes throughout the crisis. Up until then, the market for corporate control used to be the driving force for an investment-driven financial system, establishing the essential link between the firm and the capital market as its source of finance. After the outbreak of the crisis, however, new market players have taken centre stage providing liquidity in 
this market which has been close to running dry. To be sure, there have been instances of governmental participants appearing in the takeover market before, even though these participants' main purpose was to direct key industries rather than to primarily pursue objectives of an investor. The case law on Golden shares of the European Court of Justice has struck down these attempts to interfere with the market, invoking the public good as a justification. Regarding protection not for a governmental investor, but against him, in Germany the legislator only recently revised the law on foreign trade in March 2009, so that these rules now establish the authority to inspect and possibly enjoin the acquisition of $25 \%$ or more voting shares of a domestic company by an investor from outside the EU, if necessary, from the point of view of public order or security in Germany.

Since the outbreak of the financial crisis the tide has turned: foreign investors are not perceived as intruders, but rather have been welcomed as providers of desperately needed capital. Advanced economies are no longer fighting off capital injections from sovereign wealth funds, but find themselves competing for them with other countries. It stands to reason that this change raises important new governance questions that Katharina Pistor is tackling in her paper 'Sovereign Wealth Funds, Banks, and Governments in the Global Crisis: Towards a New Governance of Global Finance?'. One economic sector that is shown to be particularly affected by this financial development and by ownership by sovereign wealth funds is the financial sector. As a result, the ownership structure of banks has been consolidated and passed on to new owners, especially sovereign wealth funds or the banks' home governments, throughout the crisis. With government getting increasingly involved in the ownership of financial intermediaries, the line between ownership issues and regulatory issues is becoming blurred and the need for a framework for the governance of global finance is becoming evident. The article presents different responses under discussion in the international political arena, ranging from regulatory efforts with a predominantly international perspective, such as the Larosière Report sponsored by the European Commission, to primarily domestically oriented approaches, such as the Turner Review of the UK's Financial Services Authority. With a view to the future, one might according to the author - find a preferable solution in between, as suggested in the G30 Report that calls for domestic enforcement on the basis of internationally coordinated crisis management.

This call for effective governance of global finance is reinforced by the next empirically based article on the past and future development of sovereign wealth funds by Roland Beck and Michael Fidora. It is shown that sovereign wealth funds have undeniably experienced significant losses throughout the financial crisis. But this does not undermine the specific role played by sovereign wealth funds in global financial markets resulting from the accumulation of large external surpluses and imbalances. However, the authors point to a notable change as to financial stability with regard to sovereign wealth funds and the perception thereof in the political debate which the financial crisis has brought 
about. Contrary to certain former protectionist pressures and the growing pragmatism towards investments by those funds, the authors call for a refinement of principles of the broader objectives, of the governance and of the risk management of sovereign wealth funds that have been agreed on by an International Working Group on Sovereign Wealth Funds in the framework of the International Monetary Fund.

Such a need for global regulation of global financial institutions and their risk management is more generally dealt with in the article written by Eva Hüpkes called "Form Follows Function" - A New Architecture for Regulating and Resolving Global Financial Institutions'. The integration of individual business, especially banks, into cross-border financial groups raises difficult regulatory issues in cases of crisis, as recently illustrated by the Lehman case. On the one hand, the potential systemic effects of the failure of a bank are beyond doubt. On the other hand, large complex cross-border financial institutions consisting of multiple legal entities may produce very complex regulatory needs because of the multitude of jurisdictions involved claiming competence. That is why the author calls for an adaptation of the corporate form to its function and proposes to consolidate unregulated entities set up for tax or regulatory purposes within regulated entities in a common supervisory practice. In order to implement resolution more easily, she also advocates more effective resolution and restructuring procedures with fewer obstacles than in today's regulatory framework.

Another aspect of systemic risk is discussed in the article by Nigel Jenkinson, 'Containing System-Wide Liquidity Risks: Some Issues and Challenges', which gives an overview of liquidity risks and points out some guidelines when it comes to reducing them, and additional aspects of a possible framework to regulate them. Owing to the importance of system-wide interactions, liquidity risk raises specific regulatory questions surfacing during the current crisis. Even though liquidity risk by itself may not always pose a danger to the system, as long as the capital positions of banks are strengthened despite the obvious interrelationship between those two parameters, the current financial crisis has demonstrated the need for effective liquidity risk management. On this basis, the author sets out objectives as guidelines for an effective liquidity regulation. With a view to the desirable future regulatory development, the author calls for robust defences on the part of the banks to satisfy liquidity demands in times of market stress. In his view, banks should be discouraged from increasing liquidity risk on the basis of regulatory incentives that align their individual liquidity risk with system-wide externalities. In light of the dangers to the financial system as a whole, the stringency of regulatory standards should be sensitive to the threat emanating from the respective institution. The effectiveness of these objectives is supposed to be furthered by their consistent international application.

Carrying the issue of risk management further at the level of the individual bank, Peter Mülbert explores 'Corporate Governance of Banks' in his article. When it comes to banks, governance issues are closely tied to banking supervi- 
sion. This is because of the particularities of banks, such as their liquidityproducing function, their high leverage, their opaque balance sheets, the danger of runs that banks are subject to and their systemic importance. Looking at these factors, the author identifies agency conflicts in banks and shows that these are exacerbated in relation to the parallel conflict in generic firms and that they result in a higher risk-taking by banks. As an example of the gravity of the agency conflict in banks, consider their greater flexibility to change their portfolio of financial assets. This makes it easier for managers or shareholders to shift risks to other stakeholders on the basis of opportunistic behaviour, changing the risk profile and thus meeting performance targets or exploiting debtholders. The overall effect pointed out in the article is the larger amount of risk taken by banks in comparison with generic firms. The resulting concern about financial stability brings the supervisors into play, who have already taken a stance on corporate governance of banks on different occasions, such as the Basel Committee in its guideline 'Enhancing corporate governance for banking organisations'. After his analysis of these guidelines the author concludes that the supervisor primarily aims at the protection of depositors or other debtholders rather than at that of investors. Under conventional corporate law, this approach would make it necessary to integrate debtholders into the common purpose of the bank or to impose a fiduciary duty on the directors and officers towards depositors and other debtholders. Neither of these approaches seems viable, though. To come full circle to the current crisis, the author points out that bank-specific regulatory interference with the corporate governance of banks may by itself contribute to even more regulation. He does not consider this to be a desirable further development of corporate governance in general.

Leaving the inside of banks and turning to their relationship with their customers, Lars Klöhn focuses his attention on retail banking in his article 'Preventing Excessive Retail Investor Trading under MiFID' and examines the conduct-of-business regulation of the said Directive and its potential reformulation from a behavioural law and economics perspective. Drawing on findings of cognitive and social psychology and thus calling into question the rationality of the capital market, he considers retail investors' excessive trading to be evidence of investor overconfidence, overoptimism and biased self-attribution in capital markets. As a consequence, the MiFID regulatory system may not be sufficient to protect retail investors effectively because the financial intermediary does not have a duty to warn the customer or to stop him/her from trading. At the same time, however, the author warns not to take biases and fallacies into account on a case-by-case basis. Instead, he calls for an 'instruction manual' that ensures that cognitive psychology can be implemented into law as seamlessly as possible. The next article by Roman Inderst, called 'Retail Finance: Thoughts on Reshaping Regulation and Consumer Protection after the Financial Crisis', takes a different angle when looking at retail banking. In light of the trilateral agency problem arising between the customer, the agent and the product provider, the author 
points out as negative effects of mandatory disclosure of commissions that the roll-out of more efficient products may be stifled and market penetration slowed down. In a similar vein, mandatory minimum cancellation rights are expected to develop effectively even without a binding legal standard, which, according to the author, would offer firms the opportunity to charge higher prices. In any case, the author sees room for different regulatory approaches for different sales channels according to customers' sophistication. Even though there is some scope for psychology in consumer protection policy, the article attaches great importance to competition and its innovating force to protect consumers effectively.

Finally, a different type of investors is touched upon in the article by Ludovic Phalippou, 'Private Equity Fund Compensation Contracts and Their Incentive Effects', when private equity firms are looked at more closely. The financial relation between investors and managers of private equity funds raises agency problems that are typically dealt with in fund managers' compensation contracts. However, it is shown that these have to be employed with great care in order to be effective. Carried interest must be used in light of the danger of a strategic timing of cash flows. Transaction fees will bias managers' choices with regard to leverage, size and number of transactions envisaged.

The broad range of the papers and their interdisciplinary approaches reflect the multitude of problems and their solutions not only studied in the field of law and finance in general, but arising with particular urgency during the current financial crisis. It should also become clear that suitable solution strategies will require a careful economic analysis of the problem and a well-balanced regulatory approach to deal with it. We think that the papers published in this volume clearly show how to enter into such a fruitful interdisciplinary dialogue and we hope that they will be able to contribute to today's debate about reform in the financial sector.

Last but not least, we would like to express our gratitude to T.M.C. Asser Press and to Priv.-Doz. Dr Rainer Kulms, Editor-in-Chief of EBOR, for their willingness and support to publish the results of our conference.

Brigitte Haar* Roman Inderst** Uwe Walz***

\footnotetext{
* Professor of Law and Director of the Doctorate/PhD programme 'Law and Economics of Money and Finance' at the Goethe University of Frankfurt.

** Professor of Finance and Economics, Endowed Chair of the Stiftung Geld und Währung at the Goethe University of Frankfurt and Visiting Professor at the London School of Economics.

*** Professor of Economics and Co-Director of the Doctorate/PhD programme 'Law and Economics of Money and Finance' at the Goethe University of Frankfurt.
} 